\title{
Promotional Strategy as Maintaining Efforts User Loyalty of Information Services in Library College
}

\section{Strategi Promosi Sebagai Upaya Menjaga Loyalitas Pengguna Jasa Informasi di Perpustakaan Perguruan Tinggi}

\section{Ratih Nurhidayah dan Rini Widarti}

Gadjah Mada University
Paper Type:

Tinjauan Pustaka

Submitted 18 February 2019 Accepted 30 April 2019 Online 30 September 2019

* Correspondence: Ratih Nurhidayah

E-mail: ratihnhidayah@gmail.com

\begin{abstract}
Background of the study: Libraries have various challenges in maintaining their existence as information providers. Libraries must have support so that users do not turn to other services, have special strategies to connect themselves, establish good relationships, and provide user loyalty.
\end{abstract}

Abstract

Purpose: The purpose of this agreement is to describe the promotion strategy as an effort to encourage the loyalty of university library users.

Method: The method used in this research is literature study and also uses the author's active participation observation method as a librarian in the university library.

Findings: According to the results of research and literature study by the author, various university libraries provide various types of businesses. The results of the author's discussion there are several discussions about the library promotion strategy arrangement published; (1) Discussion of steps and targets in publicizing and promoting information services; (2) determining the promotion goals by specifying the type of user; (3) a budget is issued; (4) selecting the media used for publication and promotion; (5) evaluating various types of media that have been used; (6) the promotion process in terms of human resources, infrastructure, and various types of librarian activities.

Conclusion: With the arrangement of the strategic promotion library model, the authors submit an opinion about the college library that provides a promotional strategy as a promotional container and guarantee self-existence.

Keywords: library promotion, user loyalty, and marketing management 


\section{Abstrak}

Latar Belakang Masalah: Perpustakaan memiliki berbagai tantangan dalam mempertahankan eksistensi diri sebagai penyedia informasi. Perpustakaan harus mampu memiliki inovasi agar pengguna tidak berpaling pada layanan lainnya, memiliki strategi khusus untuk mendekatkan diri, menjalin hubungan baik, serta mampu menjaga loyalitas pengguna.

Tujuan: Tujuan dari penulisan ini adalah mendeskripsikan strategi promosi sebagai upaya menjaga loyalitas pengguna perpustakaan perguruan tinggi.

Metode: Metode yang digunakan dalam penelitian ini adalah studi pustaka serta menggunakan metode observasi partisipasi aktif penulis sebagai pustakawan di perpustakaan perguruan tinggi.

Temuan: Menurut hasil pengamatan dan studi pustaka penulis, berbagai perpustakaan perguruan tinggi melakukan berbagai jenis upaya. Hasil dari pengamatan penulis ada beberapa upaya berupa susunan strategi promosi perpustakaan yang meliputi; (1) merancang langkah dan target dalam melakukan publikasi dan promosi layanan informasi; (2) menentukan sasaran promosi dengan menspesifikasikan jenis pengguna; (3) merancang anggaran yang dikeluarkan; (4) memilih media yang digunakan untuk melakukan publikasi dan promosi; (5) melakukan evaluasi terhadap berbagai jenis media yang pernah digunakan; (6) proses promosi yang ditinjau dari sumber daya manusia, sarana prasarana, serta berbagai jenis kegiatan kepustakawanan.

Kesimpulan: Dengan adanya susunan model strategi promosi perpustakaan tersebut, maka penulis menyarankan perpustakaan perguruan tinggi mampu menyusun strategi promosi sebagai wadah inovasi dan menjaga eksistensi diri.

Kata kunci: promosi perpustakaan, loyalitas pengguna, dan manajemen pemasaran

To cite this document:

Nurhidayah, R., Widarti, R. (2019). Promotional strategy as maintaining efforts user loyalty

of information services in library college. Record and Library Journal, 5 (1), 33 - 42. 


\section{Pendahuluan}

Perkembangan teknologi melahirkan era yang baru di dalam dunia informasi. Yang mana mempunyai arti, permintaan akan suatu informasi begitu sangat penting hingga informasi mempunyai nilai ekonomi yang sangat tinggi dalam kehidupan masyarakat. Sedangkan Sutabri (2014) menjelaskan mengenai teknologi informasi merupakan teknologi yang berfungsi untuk pengolahan data, agar mendapatkan hasil yang bermutu, akurat, serta relevan. Teknologi yang berkaitan dengan mengolah suatu data menjadi sebuah informasi serta menyalurkan data ke dalam batas ruang dan waktu juga disebut sebagai teknologi informasi (Indrajit, 2011). Perpustakaan ialah salah satu dari sumber informasi yang ada di era saat ini. Sebuah perpustakaan harus bisa bersaing dalam memberikan pelayanan suatu informasi yang sangat relevan bagi pemakai. Kemudian perpustakaan juga harus bisa memajukan suatu layanan dan melangsungkan hubungan timbal balik yang baik dengan pengguna, agar tidak kehilangan penggunanya. Perpustakaan ialah suatu organisasi nonprofit, yang mempunyai tugas dalam memberikan layanan informasi kepada khalayak luas dengan memprioritaskan kepuasan para pengguna (Lasa HS, 2005:49-50).

Berbicara mengenai masalah kepuasan pengguna, Kotler (2007:35-37) menjelaskan bahwa suatu perusahaan di bidang jasa mengaplikasikan strategi pemasaran dalam membina hubungan baik, menganalisis kondisi pasar, membangun merek yang kuat, kemudian mampu mencapai kepuasan serta membangun hubungan jangka panjang, dan menyerahkan atau mengkomunikasikan nilai sebagai evaluasi kerja. Dengan adanya pemahaman tersebut, maka strategi pemasaran jasa pun bisa dilaksanakan di perpustakaan. Perpustakaan bisa menghasilkan citra yang positif serta eksistensi jika dalam penyusunan suatu strategi pemasaran jasa tepat pada sasaran yang ada. Selain itu, perpustakaan yang memulai strategi pemasaran jasa dengan memberikan pelayanan berpusat pada penggunanya juga akan menghasilkan kepuasan tersendiri bagi pengguna perpustakaan.

Sehubungan dengan hal tersebut, Purwono (2013:103) menjelaskan dalam membangun dan menciptakan suatu citra yang ada di dalam perpustakaan merupakan hal penting, agar bisa membuat para pengguna perpustakaan menjadi sangat loyal dan tidak berpaling pada pelayanan yang lainnya. Maka dari itu, perpustakaan harus memiliki strategi yang khusus untuk melakukan pendekatan terhadap pengguna, dalam membangun loyalitas untuk menunjang strategi pemasaran jasa yang ada di perpustakaan.

Setiap perpustakaan memiliki wewenang menciptakan upaya untuk menjaga loyalitas pengguna jasa dan produk informasi. Wewenang bisa meliputi berbagai jenis hal, seperti strategi mempromosikan jasa atau produk informasi; strategi pelayanan informasi; fasilitas dan layanan; serta hubungan antar sumber daya manusia (SDM) perpustakaan sendiri dengan pengguna juga termasuk di dalamnya. Perpustakaan mempunyai berbagai macam jenis, salah satunya ialah perpustakaan perguruan tinggi. Perpustakaan perguruan tinggi memiliki beberapa unit layanan termasuk perpustakaan fakultas. Pengguna jasa dan produk informasi perpustakaan perguruan tinggi lebih spesifik pada umumnya. Hal ini tentunya lebih menuntut pengelola perpustakaan dalam menjaga keloyalitasan pengguna jasa dan produk informasi perpustakaan. Perpustakaan harus senantiasa memperkenalkan serta mempublikasikan informasinya supaya pengguna yang loyal tidak hanya memiliki ketergantungan kebutuhan namun mampu merekomendasikan perpustakaan terkait kepada oengguna lain. Oleh karena itu, diperlukan strategi promosi perpustakaan sebagai salah satu upaya menjaga loyalitas pengguna jasa dan produk informasi perpustakaan.

\section{Pembahasan dan Diskusi}

\section{Perpustakaan Perguruan Tinggi}

Perpustakaan menurut Sulistyo-Basuki (1993:3) merupakan sebuah ruangan yang difungsikan untuk penyimpanan buku atau terbitan lainnya yang disusun sesuai dengan aturan dan tidak untuk diperjualbelikan, hanya boleh digunakan oleh pengguna saja. Perpustakaan perguruan tinggi merupakan salah satu jenis perpustakaan yang ada saat ini. Kemudian menurut UU Nomor 43 Tahun 2007 mengenai perpustakaan, perpustakaan yang ada di perguruan tinggi memiliki beberapa koleksi,

To cite this document:

Nurhidayah, R., Widarti, R. (2019). Promotional strategy as maintaining efforts user loyalty

of information services in library college. Record and Library Journal, 5 (1), 33 - 42. 
baik jumlah judul maupun jumlah eksemplarnya, yang mencukupi untuk mendukung pelaksanaan penelitian, pendidikan, dan pengabdian masyarakat serta mengembangkan layanan perpustakaan berbasis teknologi informasi dan komunikasi. Sehubungan dengan hal tersebut, defenisi lain juga dikemukakan oleh Sulistyo-Basuki (1993:52) menerangkan bahwa perpustakaan perguruan tinggi ialah perpustakaan yang ada di perguruan tinggi, badan bawahannya, maupun lembaga yang berada dalam satu lingkup dengan perguruan tinggi, yang mempunyai tujuan utama dalam mencapai visi dan misi perguruan tinggi sebagai lembaga induknya.

Jadi, dari pengertian di atas dapat diketahui bahwa perpustakaan perguruan tinggi ialah perpustakaan yang dilaksanakan oleh perguruan tinggi yang bertujuan untuk mendukung visi, misi, serta tercapainya tujuan perguruan tinggi yang menaunginya dengan memanfaatkan teknologi informasi dan komunikasi. Dalam konteks ini, kita juga dapat menyebutkan salah satu jenis perpustakaan yang ada di perguruan tinggi ialah perpustakaan fakultas. Fakultas merupakan bagian dari perguruan tinggi dalam bentuk departemen sebagai pendukung terwujudnya tri dharma perguruan tinggi.

\section{Layanan Perpustakaan}

Perpustakaan merupakan salah satu penyedia jasa dan produk informasi. Layanan informasi di perpustakaan disajikan dalam berbagai sistem dan jenis layanan. Menurut buku Standar Pelayanan Perpustakaan Dan Informasi Bidang Layanan Koleksi Umum Perpustakaan Nasional RI (2015: 7-9) ada tiga macam sistem layanan perpustakaan yakni; Open Access (sistem pelayanan terbuka) yang memberi kebebasan terhadap pemustaka dalam menemukan serta mencari secara langsung koleksi dan sumber informasi yang di perlukan; Close Access (sistem pelayanan tertutup) yang mana pengguna tidak boleh mengambil dan mencari secara langsung koleksi yang terdapat di dalam rak, sehingga mengharuskan pemustaka mencatat daftar bibliografi secara jelas baik judul, pengarang, atau nomor klasifikasi koleksi yang dibutuhkan; Selanjutnya adalah Mixed Access (sistem pelayanan campuran) yang umumnya memberikan layanan secara tertutup untuk layanan referensi, misalnya skripsi, laporan penelitian, koleksi referensi, tesis, dan menggunakan sistem pelayanan terbuka untuk koleksi lainnya.

Lanjutan dari hal tersebut diatas, ada beberapa jenis layanan yang tersedia di perpustakaan sebagai mana di sebutkan dalam Standar Pelayanan Perpustakaan Dan Informasi Bidang Layanan Koleksi Umum Perpustakaan Nasional RI (2015:9-15). Berbagai jenis layanan tersebut meliputi; Peyanan Sirkulasi, Pelayanan Referensi, Penelusuran Informasi, Pelayanan Bimbingan Pemustaka, Pelayanan e-Resources, Pelayanan Literasi Informasi, Pelayanan Inter-Library Loan Service atau Pinjam Antar Perpustakaan, Non Book Materials Service atau Pelayanan Koleksi Perpustakaan Bukan Buku, Pelayanan Storytelling, Pelayanan Bagi Pemustaka Berkebutuhan Khusus, Pelayanan Penyebaran Informasi Terseleksi, Pelayanan Membina Kelompok Pembaca. Dari berbagai jenis layanan perpustakaan tersebut, tidak semua diterapkan dalam layanan informasi di setiap perpustakaan. Hal itu dikarenakan setiap perpustakaan dibangun sesuai visi dan misi masing-masing. Seperti halnya perpustakaan perguruan tinggi, terutama pada perpustakaan fakultas.

Perpustakaan fakultas pada umumnya memiliki jenis jasa layanan dan produk informasi yang lebih spesifik dibandingkan dengan perpustakaan pusat sebuah perguruan tinggi. Hal ini tentu saja berpengaruh terhadap jenis pengunjung perpustakaan. Pengunjung perpustakaan perguruan tinggi pada umumnya merupakan selingkup civitas akademika baik itu dosen, pegawai atau mahasiswa. Sedangkan pada praktiknya, masyarakat umum non-instansi biasanya hanya diperbolehkan berkunjung sebagai tamu. Namun halnya, pengguna perpustakaan perguruan tinggi merupakan sekelompok pengguna yang semi homogen. Artinya, tingkat ketergantungan kebutuhan informasinya jauh lebih tinggi. Hal ini disebabkan oleh lebih spesifiknya layanan dan produk informasi yang ditawarkan. Namun halnya, terlepas dari adanya ketergangungan pemenuhan kebutuhan pengguna seharusnya perpustakaan tetap mampu menjaga loyalitas penggunanya terhadap layanan dan produk informasi yang digunakan.

To cite this document:

Nurhidayah, R., Widarti, R. (2019). Promotional strategy as maintaining efforts user loyalty

of information services in library college. Record and Library Journal, 5 (1), 33 - 42. 


\section{Promosi Jasa}

Perpustakaan merupakan salah satu penyedia jasa dan layanan informasi yang bersifat nirlaba. Dalam bukunya, Kotle (2007: 42) menjelaskan mengenai jasa yaitu suatu kinerja atau tindakan yang bisa ditawarkan kepada pihak lain, yang mana pada dasarnya jasa tidak mempunyai wujud serta tidak pula mengakibatkan adanya kepemilikan. Dikatakan pula bahwa produksinya mungkin saja terkait atau mungkin juga tidak terkait dengan produk berupa fisik. Dari definisi tersebut, jasa dan layanan informasi perpustakaan dapat kita golongkan menjadi sebuah penyedia jasa baik dalam bentuk produk (berupa fisik) dan juga dalam bentuk pelayanan yang non-fisik.

Pada dasarnya sebuah perusahaan atau lembaga jasa memiliki berbagai jenis pengguna. Beberapa perusahaan jasa menggunakan internet sebagai media mempublikasikan diri dan menjaga komunikasi dengan penggunanya. Dalam hal ini, perusahaan jasa melakukan berbagai jenis upaya supaya jasa yang ia tawarkan dikenal masyarakat umum. Keheterogenan pengguna jasa pada suatu perusahaan mendatangkan keuntungan besar terhadap pemakaian jasa perusahaan tersebut. Namun halnya, menyaring data pengguna yang lebih spesifik dianggap lebih menguntungkan secara berkala. Pengguna yang lebih spesifik yang dimaksud adalah pengguna yang loyal terhadap jasa suatu perusahaan. Pengguna yang loyal digunakan sebagai alat dan sarana komunikasi perusahaan terhadap masyarakat umum pengguna jasa (awam).

Sehubungan dengan hal tersebut, perusahaan jasa dituntut memiliki berbagai media pendukung agar pengguna yang loyal memiliki kemudahan untuk menarik pengguna lain. Kemudian, perusahaan jasa juga dianjurkan memberikan pelayanan yang lebih excelent untuk pengguna yang loyal. Hal ini dimaksudkan untuk tetap menjaga ikatan antara perusahaan dengan pengguna yang loyal atau selanjutnya disebut pelanggan. Pelanggan perusahaan jasa akan melakukan pembelian berulang serta merekomendasikan jasa terkait kepada orang lain. Sebagai contoh, pemberian voucher atau diskon sebagai promo penggunaan layanan dan jasa adalah upaya menjaga hubungan baik antara pelanggan dengan perusahaan.

Hal tersebut diatas kita definisikan sebagai strategi promosi perusahaan jasa. Strategi ialah instrumen untuk pencapaian suatu maksud dan tujuan sebuah perusahaan dalam waktu jangka panjang, prioritas sumber daya, dan program tindak lanjut perusahaan (Rangkuti, 2001). Lain halnya dengan Kotler (2000) yang menjelaskan tentang strategi merupakan rencana yang digunakan dalam mencapai sasaran yang diharapkan dari unit suatu bisnis. Promosi perusahaan jasa bisa dilakukan secara langsung maupun tidak langsung (melalui media). Promosi secara langsung bisa dilakukan dengan cara memberikan pelayanan terbaik kepada pelanggan sehingga pelanggan merasa puas dan melakukan penggunaan berulang. Hal itu bisa dilakukan dengan cara menyiapkan SDM pelayanan yang berkualitas; ketersediaan produk jasa yang lengkap dan relevan sesuai kebutuhan; serta sarana prasarana yang mendukung terjadinya proses transaksi jasa. Sedangkan promosi secara tidak langsung bisa meliputi penyebarluasan produk jasa melalui internet (media sosial); penggunaan media promosi (poster, banner, leaflet, brosur, dsb); pemberikan promo, diskon, voucher, dan pemberian gift atau reward bagi pelanggan terbaik; serta pengadaan event-event yang menarik pelanggan.

Selain upaya menyusun strategi promosi, perusahaan jasa secara regeneratif harus memperhatikan beberapa hal yang mempengaruhi kualitas jasa yang disediakan. Seperti disebutkan oleh Kotler (2007:56) bahwa ada beberapa hal pokok yang harus diperhatikan sebagai penentu kualitas suatu jasa antara lain adalah; Keandalan dalam melaksanaan proses pelayanan secara menjanjikan dan akurat; Daya tanggap dalam meberikan layanan jasa dalam waktu yang cepat; Jaminan untuk menanamkan kepercayaan dan keyakinan di benak pelanggan yang terlihat dari kecakapan dan cara melayani pelanggan; Empati yang tinggi terhadap kebutuhan pelanggan sehingga pelanggan merasa diperhatikan; Serta benda berwujud dalam wujud fisik produk jasa, karyawan, fasilitas dan alat bantu promosi lainnya.

\section{Loyalitas Pengguna Jasa}

Berbicara mengenai loyalitas pengguna, dalam istilah marketing hal ini sering disebut dengan

To cite this document:

Nurhidayah, R., Widarti, R. (2019). Promotional strategy as maintaining efforts user loyalty

of information services in library college. Record and Library Journal, 5 (1), 33 - 42. 
customer loyality. Assauri (2012:14-15) memaparkan bahwa loyalitas pengguna atau pelanggan mempunyai kecenderungan untuk memilih nilai organisasi yang ditawarkan sebagai pilihan tawaran alternatif dalam beberapa organisasi pesaing. Pernyataan tersebut didukung dengan pendapat Collins dalam Lucas (2005:316) yang menuliskan "Customer loyality means that the customer appreciates and value what you do for him or her and trusts and likes you enough that he or she chooses to come to see you instead of someone else. It also means that the customer would recommend you to family and friends". Artinya, loyalitas pengguna merupakan bentuk apresiasi dan nilai dari pengguna atau pelanggan terhadap apa yang anda (pemasar) lakukan untuknya, sehingga terbentuk rasa suka dan percaya kepada pelayanan yang anda berikan serta akan merasa puas karna telah memilih anda, bukan orang lain. Kemudian pelanggan akan merekomendasikan anda kepada keluarga dan teman-temannya. Sedangkan dalam kaitannya dengan perpustakaan, istilah pengguna sering disebut dengan istilah pemustaka. Hal ini dinyatakan dalam Undang-Undang Nomor 43 tahun 2007 tentang Perpustakaan bahwa pemustaka adalah pengguna perpustakaan, yaitu perseorangan, kelompok orang, masyarakat, atau lembaga yang memanfaatkan fasilitas layanan perpustakaan. Dengan demikian, pemaparan sebelumnya dapat dikaitkan dengan kondisi perpustakaan sebagai organisasi jasa non-profit sehingga menghasilkan redifinisi baru tentang loyalitas pengguna perpustakaan.

Jadi, dapat dipahami bahwa loyalitas pengguna perpustakaan merupakan sifat percaya pengguna dalam memanfaatkan layanan serta fasilitas di dalam perpustakaan. Loyalitas pengguna perpustakaan berperan untuk membentuk suatu komunitas atau sekelompok pengguna potensial terhadap jasa dan layanan informasi dari suatu perpustakaan. Pengguna perpustakaan yang loyal merupakan gerbang utama pelanggan perpustakaan yang akan secara otomatis membangun jaringan kerjasama dalam upaya membentuk pasar sasaran dari perpustakaan. Jika suatu relasi dari pasar perpustakaan sudah terbentuk, maka peraihan citra positif serta keberhasilan dari tujuan pemasaran jasa dan layanan informasi perpustakaan akan tercapai secara maksimal.

Berkaitan dengan hal tersebut, menurut Griffin (2005:31) karakteristik pengguna yang loyal meliputi berbagai jenis hal. Melakukan pembelian berulang secara teratur (makes reguler repeat purchase) yang mana dalam hal ini tingkat kepuasan pengguna terhadap perpustakaan akan mempengaruhi mereka datang kembali untuk menggunakan fasilitas perpustakaan. Selanjutnya adalah pembelian purchases across product and service lines atau di luar lini produk / jasa dimana pengguna yang sudah percaya pada layanan perpustakaan tertentu dalam pemenuhan kebutuhan informasi maka akan tetap datang dan percaya dengan mengesampingkan urusan lain seperti halnya pelayanan. Kemudian, pengguna mereferensi perusahaan kepada orang lain, maksudnya adalah memikat pelanggan yang baru untuk kepentingan perusahaan (refers other). Pengguna yang loyal akan melakukan tindakan sukarela untuk merekomendasikan perpustakaan kepada rekan mereka. Pengguna akan menunjukkan ketahanan daya tarik dari pesaing yang ada (Demonstrates an immunity to the full of the competition). Dimana pengguna tidak mudah dipengaruhi oleh tarikan persaingan sumber informasi yang lainnya (seperti perpustakaan lain, toko buku, bahkan internet).

Maka dengan demikian, dapat dianalisa bahwa pengguna perpustakaan perguruan tinggi khususnya perpustakaan fakultas mampu dikategorikan sebagai pengguna yang loyal terhadap jasa dan produk informasi perpustakaan. Sehubungan dengan itu, maka perlu adanya upaya dalam menjaga loyalitas pengguna tersebut.

\section{Promosi Jasa dalam Menjaga Loyalitas Pengguna Perpustakaan}

Perpustakaan merupakan salah satu jenis lembaga penyedia jasa informasi. Terkait dengan strategi promosi, penyedia jasa informasi memiliki berbagai jenis upaya. Hanya saja, berbeda dengan perpustakaan yang memiliki jenis layanan informasi yang bersifat lebih spesifik dengan pengguna yang semi homogen, misalnya, perpustakaan perguruan tinggi, yang mana memiliki pengguna dalam lingkup civitas akademika (dosen, staff dan mahasiswa). Dalam hal ini pengguna dianggap sebagai fokus utama dalam transaksi pelayanan jasa. Civitas akademika sebagai pengguna utama, beberapa di antaranya diklasifikasikan sebagai pengguna yang loyal bagi perpustakaan perguruan tinggi.

To cite this document:

Nurhidayah, R., Widarti, R. (2019). Promotional strategy as maintaining efforts user loyalty

of information services in library college. Record and Library Journal, 5 (1), 33 - 42. 
Sedangkan pengguna pada umumnya merupakan pengguna eksternal, berasal dari masyarakat umum, lembaga, instansi pemerintah atau perguruan tinggi lainnya.

Sehubungan dengan hal di atas, seperti dituliskan oleh Kotler (1995: 697-715) ada beberapa tahapan periklanan dan promosi suatu perusahaan nirlaba. Beberapa tahapan tersebut antara lain adalah; merencakanan periklanan; menentukan sasaran periklanan; menentukan anggaran periklanan; menentukan media; evaluasi media; hingga tahap promosi itu sendiri. Hal ini ditekankan supaya strategi promosi yang dirancang mampu mencapai target utama promosi yakni menarik pengguna, mencapai kepuasan pengguna, membentuk loyalitas pelanggan, mempertahankan pelanggan, dan memberdayakan pelanggan sebagai stakeholder yang membantu penyebarluasan informasi perpustakaan sehingga menarik pengguna lain.

Pada tahap pertama, dalam perencanaan periklanan perpustakaan dituntut memiliki Sumber Daya Manusia (SDM) yang selanjutnya disebut sebagai pustakawan yang mampu diandalkan sesuai bidangnya. Lain dari itu, pustakawan tidak hanya diwajibkan untuk berdedikasi tinggi namun juga dituntut untuk berinovasi dalam mengikuti perkembangan. Jenis iklan yang sesuai dirancang dalam menyusun strategi promosi adalah refleksi iklan perusahaan jasa. Iklan untuk perusahaan jasa sebagaimana diungkapkan oleh Kotler (2007:67-69) bahwa dalam menyusun perencanaan periklanan jasa harus memperhatikan pemilihan unsur merek, penetapan dimensi citra, serta perancangan strategi pemerekan (branding). Dalam hal ini, pustakawan harus mampu mendekripsikan secara singkat terkait produk jasa yang ada di perpustakaan. Sebagai contoh, pustakawan cakap dalam melayani pengguna pada layanan referensi. Kemampuan itu dapat dilihat dari kecakapan berkomunikasi, mempresentasikan kembali jenis informasi, mencarikan bahan koleksi yang relevan dengan kebutuhan pengguna, hingga pengguna merasa puas atas kebutuhan informasinya. Selain layanan referensi, layanan lainnya yang disediakan oleh perustakaan juga wajib menjadi perhatian. Bagaimana cara menciptakan "something unique" dari perpustakaan itu sendiri. Karena pada dasarnya, produk jasa yang akan diiklankan dalam perpustakaan meliputi dua hal pokok yakni koleksi sebagai produk fisik dan layanan sebagai produk jasa non-fisik. Sebagai contoh implementasi dalam perpustakaan perguruan tinggi. Salah satu contohnya adalah Perpustakaan FEB UGM (Fakultas Ekonomika dan Bisnis Universitas Gadjah Mada) yang menggunakan sistem RFID pada layanan sirkulasi. Hal ini tentu melahirkan inovasi teknologi informasi baru di dunia perustakaan. Sama halnya dengan perpustakaan FEB UGM, Perpustakaan pusat UIN Sunan Kalijaga Yogyakarta juga menggunakan sistem RFID. Hanya saja, yang membuat lebih unique dan canggih adalah perpustakaan UIN Sunan Kalijaga sudah dilengkapi dengan mesin layanan pinjam-kembali mandiri. Sehingga pengguna bisa melakukan kontrol penuh terhadap kegiatan sirkulasi. Adanya perencanaan periklanan yang komprehensif akan membuat pelanggan merasa mudah menggunakan layanan perpustakaan. Kemudian hal itu akan membentuk kepuasan, adanya keinginan untuk kembali, bahkan kepercayaan serta keyakinan untuk merekomendasikan layanan kepada pengguna lain.

Pada tahap kedua, upaya menentukan sasaran periklanan. Pada tahap ini perpustakaan harus memiliki beberapa strategi melakukan publikasi layanan informasi atau promosi. Hal ini dianggap penting karena telah disebutkan sebelumnya bahwa pengguna perpustakaan merupakan pelopor utama terbentuknya suatu perpustakaan. Perpustakaan perguruan tinggi yang pada notabennya memiliki pengguna semi homogen, dituntut memiliki rancangan strategi promosi sesuai dengan jenis dan kebutuhan penggunanya. Sebagai contoh implementasi strategi promosi yang tepat sasaran pada perpustakaan perguruan tinggi. Perpustakaan UIN Sunan Kalijaga mengadakan beberapa event sebagai ajang promosi layanan perpustakaan kepada penggunanya. Pengguna perpustakaan UIN Sunan kalijaga mayoritas adalah civitas akademika berbasis keislaman. Penyelenggaraan event berbasis keislaman menjadikan beberapa pengguna perpustakaan UIN mengikat loyalitas terhadap layanan informasi perpustakaan. Contoh lain, pada perpustakaan FEB UGM dalam pengadaan pelatihan akses database keuangan OSIRIS. Pengguna perpustakaan FEB UGM merupakan selingkup mahasiswa dan masyarakat yang berlatar belakang dunia ekonomi dan bisnis. Hal itu merupakan upaya yang dilakukan atas dasar penentuan sasaran periklanan. Bercermin pada beberapa macam 
upaya yang dilakukan, maka sebaiknya perpustakaan perguruan tinggi memang memperhatikan sasaran periklanan sebelum melakukan promosi jasa dan layanan informasi. Hal tersebut perlu diperhatikan guna membatasi dan memfokuskan strategi promosi kepada pengguna yang diprediksi dapat meningkatkan nilai jasa informasi. Pengguna yang dapat meningkatkan nilai jasa ini yang nantinya akan menjadi pelanggan loyal terhadap informasi perpustakaan dan mampu menjadi stakeholder yang bekerjasama menarik pengguna lain untuk berkunjung.

Tahap ketiga adalah penentuan anggaran dalam periklanan. Keadaan pengguna jasa informasi perpustakaan perguruan tinggi yang semi homogen berpengaruh besar terhadap anggaran yang digunakan dalam mempublikasi dan mengiklankan jasa informasi. Lebih spesifiknya pengguna jasa informasi pada suatu perpustakaan perguruan tinggi, seharusnya justru lebih menekan pengeluaran anggaran periklanan yang ada. Tidak hanya dari segi pendanaan, dari segi efisiensi waktu juga seharusnya mampu menekan anggaran dalam periklanan. Sebagai refleksi, adanya pelatihan akses database keuangan OSIRIS pada perpustakaan FEB UGM sebagai strategi mempromosikan jasa informasi. Pelatihan akses database OSIRIS diperuntukkan untuk civitas akademika. Pada umumnya pendatang hanya akan berasal dari bidang ekonomika dan bisnis atau beberapa khalayak yang membutuhkan informasi terkait database keuangan saja. Hal ini tentu akan menekan penggunaan anggaran periklanan. Hal itu dikarenakan, perpustakaan FEB UGM hanya memerlukan tata ruang yang tidak terlalu luas untuk menampung beberapa khalayak umum. Kemudian, perpustakaan FEB UGM juga menekan anggaran dalam menyediakan media pendukung. Oleh karena itu perpustakaan FEB UGM sudah berlangganan database OSIRIS, sehingga peserta tidak memerlukan media pendukung lain dalam pelaksanaan pelatihan tersebut. Perencanaan dan penentuan jumlah anggaran periklanan jasa perpustakaan wajib diperhatikan dalam membangun strategi promosi sebagai upaya menjaga loyalitas pengguna jasa informasi. Semakin minimal anggaran yang digunakan atau dibutuhkan, maka tingkat kepercayaan pengguna perpustakaan akan meningkat pula. Hal ini dapat dilihat dari berbagai macam contoh seperti dana pelatihan tersebut sebelumnya. Semakin minim total anggaran yang dikeluarkan oleh pengguna jasa dalam mendapatkan informasi, akan membuat pengguna jasa memiliki tingkat kepuasan akan pemenuhan kebutuhan informasi. Kemudian tingkat kepercayaan yang kuat akan efisiensi dana dalam mendapatkan informasi bernilai tinggi membentuk keinginan untuk kembali ketergantungan dalam penggunaan akan jasa informasi yang ditawarkan perpustakaan.

Tahap keempat yakni penentuan media periklanan jasa informasi perpustakaan. Dalam tahap ini pemilihan jenis media yang digunakan perpustakaan untuk mempublikasi layanan dan mempromosikan layanannya sangat berpengaruh besar terhadap minat pengguna. Pada implementasinya perpustakaan perguruan tinggi dapat melakukan berbagai jenis media sebagai sarana publikasi dan promosi. Seperti pada perpustakaan FEB UGM, menggunakan website pada laman http://www.lib.feb.ugm.ac.id/; akun media sosial seperti instagram dan twitter sebagai media menyampaikan informasi terkait perpustakaan. Selain hal tersebut, penggunaan banner dan poster sebagai media promosi juga diupayakan perpustakaan FEB UGM. Kemudian pembuatan video profil perpustakaan juga digunakan pengguna perpustakaan sebagai media promosi serta membantu kegiatan user education bagi mahasiswa baru di FEB UGM. Lain halnya dari perpustakaan FEB UGM, perpustakaan perguruan tinggi lain seperti perpustakaan UIN Sunan Kalijaga justru memiliki metode yang lebih unik dari media berupa benda mati. Perpustakaan UIN Sunan Kalijaga memiliki Ikatan Sahabat Perpustakaan yang disebut sebagai tenaga Part timer Mahasiswa Perpustakaan UIN Sunan Kalijaga, digunakan sebagai sarana promosi layanan perpustakaan kepada pengguna lain. Sehingga informasi terkait layanan perpustakaan justru tersampaikan melalui sumber yang terpercaya dan meyakinkan. Seharusnya, perpustakaan perguruan tinggi memang memiliki inovasi dalam menciptakan media promosi. Agar terkesan menarik dan membuat mahasiswa terutama sebagai pengguna yang loyal, tidak lagi berpaling menggunakan sumber informasi lain yang menyebabkan maraknya kasus plagiarisme.

Tahap kelima adalah evaluasi media promosi. Pada tahap ini merupakan kelanjutan pada tahap

To cite this document:

Nurhidayah, R., Widarti, R. (2019). Promotional strategy as maintaining efforts user loyalty

of information services in library college. Record and Library Journal, 5 (1), 33 - 42.

Open access under Creative Commons Attribution-Non Commercial-Share A like 4.0 International Licence

(CC-BY-SA) 
Ratih Nurhidayah | Promotional strategy as maintaining efforts user loyalty of information services in library college

selanjutnya. Untuk menjaga keberlangsungan tingkat loyalitas pengguna jasa informasi perustakaan perguruan tinggi, maka perpustakaan harus senantiasa mampu mengevaluasi berbagai jenis strategi yang sudah pernah diupayakan. Hal ini dilakukan guna meninjau kembali, apakah upaya sebelumnya mencapai target dan sasasaran promosi. Kemudian perlukah diadakan inovasi bahkan perubahan strategi secara total melalui evaluasi kelayakan media yang digunakan sebelumnya.

Tahap kelima dan terakhir adalah proses melakukan promosi itu sendiri. Karena pada dasarnya setiap unsur yang ada di perpustakaan merupakan sarana promosi jasa dan layanan infornasi bagi penggunanya. Ketersediaan sumber daya manusia perpustakaan atau pustakawan dalam melakukan pelayanan berpengaruh juga dalam membentu rasa percaya dan loyalitas pengguna. Sebagai contoh, perpustakaan UIN Sunan Kalijaga mengenakan beberapa baju adat pada hari-hari besar tertentu agar terkesan unique serta menanamkan kewajiban senyum, sapa, salam kepada setiap pengguna sehingga pengguna merasa terapresiasi. Selanjutnya, kemudahan akses dan pemenuhan kebutuhan informasi. Perpustakaan Universitas Gadjah Mada menerapkan layanan perpustakaan terintegrasi. Dengan adanya layanan temu kembali informasi pada http://opac.lib.ugm.ac.id perpustakaan Universitas Gadjah Mada menjembatani pelanggannya menemukan informasi dari seluruh unit perpustakaan yang ada di Universitas Gadjah Mada. Hal itu justru membuat mudah pengguna mengakses informasi pada satu jalan yang sama tanpa harus mencari dari berbagai jenis sumber temu kembali informasi yang membingungkan. Kemudian kegiatan promosi itu sendiri, seperti adanya kegaitan user education yang dilakukan perpustakaan perguruan tinggi khususnya pada saat penerimaan mahasiswa baru. Upaya ini dilakukan untuk menanamkan pengetahuan tentang layanan perpustakaan dan menanamkan rasa percaya pada pengguna terkait pemenuhan kebutuhan informasi mereka selama menyelesaikan study di universitas tersebut. Lain dari kegiatan user education perpustakaan juga sebaiknya aktif melakukan kegiatan lain terkait peningkatan pengetahuan pengguna sesuai dengan visi dan misi perpustakaan. Seperti contoh, perpustakaan UIN Sunan Kalijaga kerap melakukan acara bedah buku terkait bidang keislaman yang sesuai dengan latar belakangnya sebagai universitas keislaman. Selaras dengan itu, pelatihan penggunaan akses database OSIRIS yang dilakukan perpustakaan FEB UGM juga diupayakan sebagai strategi mempertahankan ketergantungan pengguna kepada layanan informasi perpustakaan.

Dari uraian tersebut dapat disimpulkan bahwa perpustakaan perguruan tinggi negeri perlu melakukan berbagai jenis upaya mempublikasi dan mempromosikan layanan informasinya. Hal ini dilakukan dengan tujuan menjaga citra dan mengikat mahasiswa sebagai stakeholder yang diharapkan mampu memberi nilai serta meregenerasikan nilai kepada pengguna di luar lingkup keanggotaan. Dengan demikian, layanan informasi perpustakaan perguruan tinggi akan mampu berjalan sesuai dengan tugas utama perpustakaan sebagai wahana informasi masyarakat. Kesetiaan atau bisa disebut juga loyalitas pengguna terhadap perpustakaan perguruan tinggi dianggap mampu mendongkrak perpustakaan melakukan inovasi dalam memperbaiki layanannya.

\section{Simpulan}

Perpustakaan perguruan tinggi sebagai jantung universitas dalam melaksanakan visi dan misi sesuai tri dharma perguruan tinggi, memiliki kewajiban mendukung secara penuh dengan berbagai upaya. Wewenang melakukan publikasi dan promosi layanan perpustakaan mendorong perpustakaan untuk berinovasi menciptakan kesadaran dan pribadi civitas akademika pada khususnya akan pentingnya informasi. Strategi promosi merupakan suatu upaya yang dilakukan lembaga informasi untuk menjaga citra, meningkatkan minat kunjungan serta menanamkan ketergantungan pengguna terhadap jasa dan layanan informasi yang disajikan di lembaga tersebut. Lain halnya seperti perpustakaan perguruan tinggi juga harus memiliki stratagi menjaga kepercayaan civitas akademika sebagai pengguna bahkan pelanggan inforamasi perpustakaan.

Pada umumnya, merancang strategi promosi perpustakaan perguruan tinggi diwujudkan dalam berbagai upaya. Seperti merancang langkah-langkah dan target dalam melakukan publikasi dan promosi layanan informasi. Kemudian adanya upya menentukan sasaran promosi dengan

To cite this document:

Nurhidayah, R., Widarti, R. (2019). Promotional strategy as maintaining efforts user loyalty

of information services in library college. Record and Library Journal, 5 (1), 33 - 42.

Open access under Creative Commons Attribution-Non Commercial-Share A like 4.0 International Licence

(CC-BY-SA) 
menspesifikasikan jenis pengguna jasa dan layanan perpustakaan. Didampingi dengan adanya rancangan anggaran yang dikeluarkan sehingga dapat ditekan dan tidak membuat pengguna kesulitan mendapatkan informasi dengan nilai tinggi seperti upaya menerapkan sistem kerjasama. Selanjutnya adalah pemilihan media yang digunakan untuk melakukan publikasi dan promosi. Sehubungan dengan pemilihan media, kedepannya perpustakaan juga harus melakukan evaluasi terhadap berbagai jenis media yang pernah digunakan. Agar terjaga kelayakan dan terukur guna melakukan inovasi kedepannya. Lalu yang terakhir adalah proses terjadinya promosi itu sendiri, baik dalam keseharian ditinjau dari sumber daya manusia dalam melaksanakan tugas kepustakawanan dan komunikasi pengguna. Atau ditinjau dari ketersediaan sarana prasarana, serta beberbagai jenis kegiatan yang dilakukan.

Upaya strategi promosi perpustakaan perguruan tinggi harus tetap diberlangsungkan agar civitas akademika terutama sebagai pengguna atau stakeholder perpustakaan mendapatkan kepuasan pemenuhan kebutuhan informasi. Lain dari itu, pengguna yang puas akan mampu meberi nilai guna pendongkrak inovasi layanan perpustakaan serta sebagai jembatan meregenerasikan informasi kepada pengguna lain sehingga menarik minat kunjung pengguna lainnya.

\section{Referensi}

Assauri, Sofjan. (2012). Stategic Marketing: Sustaining Lifetime Customer Value. Ed.1. Jakarta: Rajawali Pers.

Griffin, Jill. (2005). Customer Loyality: Menumbuhkan dan Mempertahankan Kesetiaan Pelanggan. Jakarta: Erlangga.

Indrajit, Richardus Eko. 2011. Peranan Teknologi Informasi dan Internet. Yogyakarta: Andi Offest.

Kotler, Philip. (2000). Marketing Management. Edisi Milenium. Inc New Jersey: Prentice Hall Intl.

Kotler, Philip (2000). Prinsip -Prinsip Pemasaran Manajemen. Jakarta: Prenhalindo.

Kotler, Philip dan Kevin Lane Keller. (2007). Manajemen Pemasaran. Edisi 12 Bahasa Indonesia (Jilid 1). Jakarta: Indeks.

Kotler, Philip dan Kevin Lane Keller. (2007). Manajemen Pemasaran. Edisi 12 Bahasa Indonesia (Jilid 2). Jakarta: Indeks.

Kotler, Philip dan Kevin Lane Keller. (2007). Manajemen Pemasaran. Edisi 13 Bahasa Indonesia (Jilid 1). Jakarta: Indeks.

Kotler, Philip dan Andreasen, Alan R. (1995). Strategi Pemasaran Untuk Organisasi Nirlaba Edisi Ketiga. Yogyakarta: Gadjah Mada Press

Lasa HS. (2005). Manajemen Perpustakaan. Yogyakarta: Gama Media.

Lucas, Robert W. (2005). Customer Service: Building Succesfull Skills for The Twenty-first Century. Third edition. New York: McGraw Hill Irwin.

Pemerintah Republik Indonesia. (2007). Undang-Undang Nomor 43 Tahun 2007 Tentang Perpustakaan. Indonesia: Pemerintah Republik Indonesia.

Perpustakaan Nasional RI. (2015). Standar Pelayanan Perpustakaan Dan Informasi Bidang Layanan Koleksi Umum Perpustakaan Nasional RI. Jakarta: Perpustakaan Nasional RI.

Purwono. (2013). Profesi Pustakawan Menghadapi Tantangan Perubahan. Yogyakarta: Graha Ilmu.

Rangkuti, Freddy. (2001). Analisis SWOT Teknik Membedah Kasus Bisnis. Jakarta: Gramedia Pustaka Utama.

Sulistyo-Basuki. (1993). Pengantar Ilmu perpustakaan. Jakarta: Gramedia.

Sutabri, Tata. (2014). Pengantar Teknologi Informasi. Edisi Pertama. Yogyakarta: Penerbit Andi.

To cite this document:

Nurhidayah, R., Widarti, R. (2019). Promotional strategy as maintaining efforts user loyalty

of information services in library college. Record and Library Journal, 5 (1), 33 - 42. 